\title{
POTENSI BIJI JINTAN HITAM (NIGELLA SATIVA) DALAM REGENERASI PANKREAS SECARA ENDOGEN PADA DIABETES MELLITUS TIPE-2
}

\author{
Fathiyah Safithri \\ Fakultas Kedokteran Universitas Muhammadiyah Malang \\ j1. Bendungan Sutami No. 188A Malang
}

Email : fathiyahsafithri@yahoo.com

\begin{abstract}
ABSTRAK
Penurunan massa sel-â pankreas terjadi pada sebagian besar pasien diabetes melitus tipe-II dan hal ini berlangsung secara progresif. Pankreas merupakan salah satu organ yang mempunyai kemampuan meregenerasi dirinya sendiri dalam upaya mempertahankan massa sel-â. Regenerasi dapat terjadi melalui replikasi sel-â matur, diferensiasi/ transdiferesiasi sel punca/ progenitor. Keadaan resistensi insulin yang berlangsung secara kronik menyebabkan kemampuan regenerasi tersebut menurun. Biji jintan hitam (Nigella sativa) yang mengandung bioaktif thymoquinone, asam oleat, asam linoleat dan saponin berpotensi meningkatkan kemampuan regenerasi pankreas secara endogen melalui stimulasi proses replikasi sel-â, mempengaruhi niche dan mengaktivasi sel punca endogen.
\end{abstract}

Kata kunci : diabetes mellitus type II, massa sel-â pankreas, regenerasi pankreas endogen, replikasi, diferensiasi, jintan hitam

\begin{abstract}
Decreasing pancreatic â-cell mass occurs in the majority of patients with type II diabetes mellitus and this progresses progressively. Pancreas is one of the organs that have the ability to regenerate itself in an effort to maintain the â-cell mass. Regeneration can occur through mature cell-beta replication or stem cell / progenitor differentiation / transdifferentiation. The state of chronic insulin resistance causes decreasing pancreatic regeneration ability. Black cumin seeds (Nigella sativa) contains bioactive thymoquinone, oleic acid, linoleic acid and saponin that potentially increase endogenous pancreatic regeneration through stimulate $\hat{a}$-cell replication, affect the stem cell niche and activate endogenous stem cells.
\end{abstract}

Keywords : diabetes mellitus type II, pancreatic â-cell mass, endogenous pancreatic regeneration, replication, differentiation, black cumin

\section{PENDAHULUAN}

Diabetes Mellitus (DM) merupakan suatu kelompok penyakit metabolik dengan karakteristik hiperglikemia yang terjadi karena kelainan sekresi insulin, kerja insulin atau kedua-duanya. Pada tahun 2020, jumlah penderita DM tipe 2 diperkirakan akan mencapai 250 juta orang di seluruh dunia (ADA, 2004). Indonesia saat ini menduduki rangking ke-empat jumlah penderita diabetes setelah Amerika Serikat, China dan India. Berdasarkan data dari Badan Pusat Statistik (BPS) jumlah penderita diabetes pada tahun 2003 sebanyak 13,7 juta orang dan diperkirakan pada 2030 ada 20,1 juta penderita diabetes, sekitar $80 \%-90 \%$ dari jumlah tersebut adalah DM tipe 2. Tingginya prevalensi DM tipe II diperkirakan juga akan memicu kenaikan komplikasi DM seperti penyakit jantung iskemik, stroke, neuropati, retinopati, dan nefropati. 
Resistensi insulin merupakan patogenesis utama DM tipe-II. Keadaan resistensi insulin awalnya akan menyebabkan respon kompensasi pada pankreas, namun bila hal ini berlangsung kronik akan menyebabkan berkurangnya massa sel-â secara progresif. Kehilangan massa sel-â akan semakin menurunkan kadar insulin dalam darah (Rhodes, 2005)

\section{Kemampuan Kompensasi Pankreas dalam Kondisi Resistensi Insulin}

Diabetes mellitus tipe II ditandai dengan produksi glukosa hepar yang berlebihan, penurunan sekresi insulin, dan resistensi insulin. Resistensi insulin merupakan patogenesis utama DM tipe II dan terjadi mendahului onset DM. Keadaan resistensi insulin ini ditandai dengan ketidakmampuan insulin untuk merangsang uptake glukosa oleh jaringan target, seperti otot dan lemak. (Saini, 2010). Pada awal keadaan resistensi insulin, glukotoksisitas dan lipotoksisitas menginduksi pankreas melakukan upaya kompensasi dengan cara meningkatkan sekresi insulin untuk mempertahankan keadaan normoglikemi. Peningkatan sekresi insulin terjadi antara lain melalui peningkatan massa sel-â dan atau peningkatan fungsi sel-â. Penelitian terdahulu membuktikan terjadi peningkatan massa sel-â pada pasien obesitas, hal yang sama juga terjadi selama kehamilan (Jetton, 2005). Peningkatan massa sel-â distimuli terutama oleh FFA. FFA merangsang peningkatan sekresi GLP-1 oleh sel L di intestin. GLP-1 meningkatkan proliferasi sel-â (Prentki, 2006).

Untuk mengkompensasi keadaan hiperglikemi, pankreas juga melakukan upaya kompensasi berupa peningkatan fungsi sel-â (Gambar 1). Hal tersebut terjadi akibat stimuli peningkatan metabolisme glukosa di sel-â, sinyaling lipid (FFA), GLP-1, aktivasi parasimpatis, inhibisi simpatis atau up-regulasi ekspresi gen insulin (Prentki, 2006). Metabolisme glukosa melalui perubahan piruvat menjadi acetyl $C_{0}-A$ dan oksidasi di mitokondria akan meningkatkan rasio ATP/ADP di sel-â. Selanjutnya terjadi penutupan kanal $\mathrm{K}$ yang sensitif ATP, depolarisasi membran plasma, pembukaan kanal $\mathrm{Ca}^{2+}$ dan peningkatan $\mathrm{Ca}^{2+}$ yang mencetuskan eksositosis insulin. FFA meningkatkan sekresi insulin melalui dua mekanisme, pertama interaksi FFA dengan reseptor FFA-1/GPR40 pada membran akan mengaktivasi sinyal intraseluler dan meningkatkan $\mathrm{Ca}^{2+}$. Kedua, melibatkan interaksi antar anaplerosis yang menghasilkan malonyl-Co $A$ dan LC-CoA (Roduit, 2004).

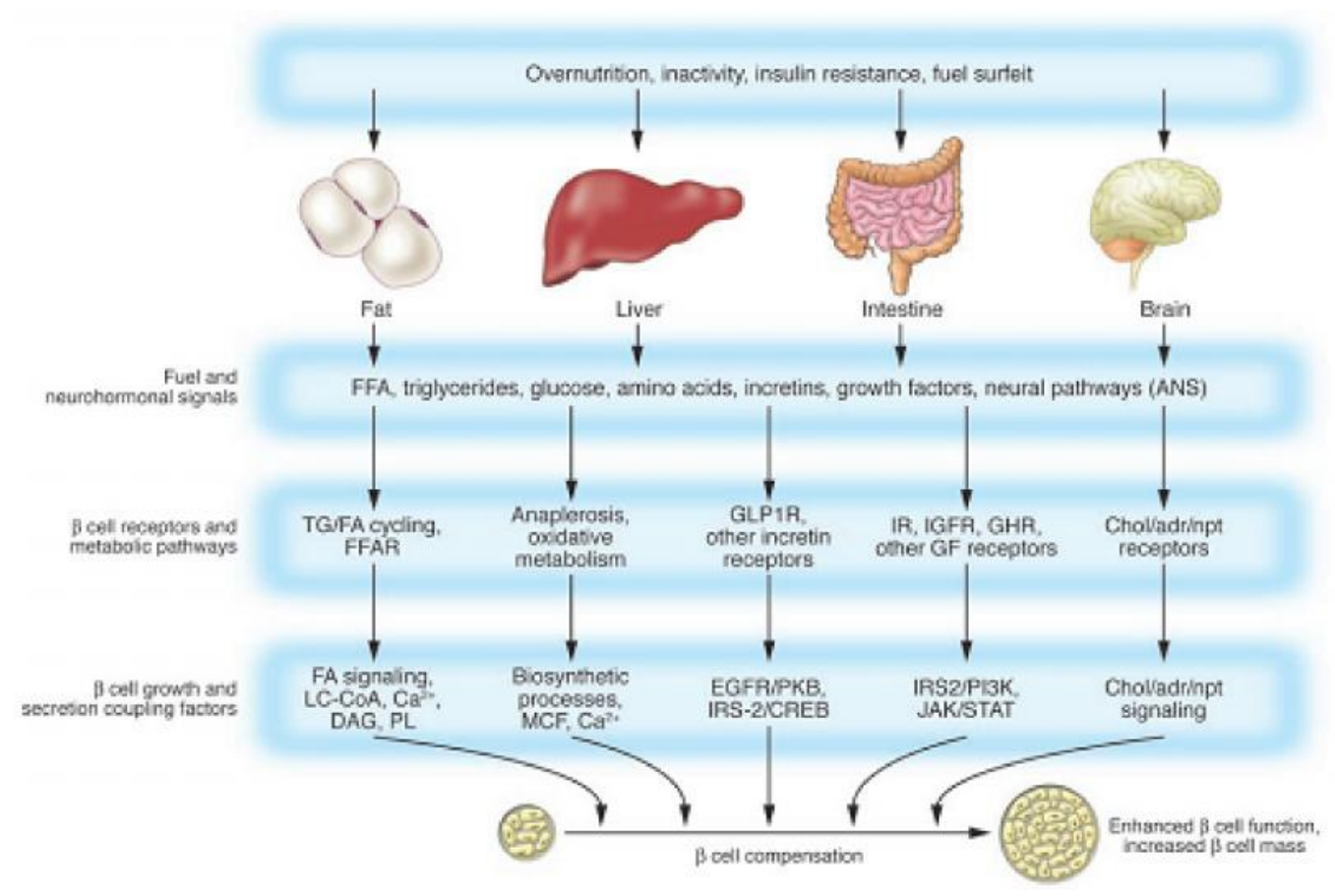

Gambar 1. Faktor yang Menstimuli Reaksi Kompensasi Sel-â (Prentki, 2006) 
Regulasi transkripsi gen insulin melibatkan interaksi kompleks antara sinyal second messenger dari metabolisme nutrien dan rangsangan hormon (misalnya $P 13 \mathrm{~K}$ dan $p 38 \mathrm{MAPK}$ ), faktor transkripsi (misalnya $P d x 1$, mafA, Beta2/Neuo D) dan beberapa faktor transkripsi $D N A$ binding site. Glukosa dan GLP-1 merupakan stimulator utama untuk aktivasi transkripsi gen insulin dan selanjutnya terjadi upregulasi biosintesa insulin (Prentki, 2006)

Peningkatan metabolisme oksidasi glukosa dan FFA di mitokondria akan meningkatkan membran potensial mitokondria dan produksi superoksid. Peningkatan produksi superoksid menyebabkan paparan sel terhadap ROS meningkat dan terjadi aktivasi uncoupling protein-2 (UCP2). Glukotoksiksistas dan lipoksisitas yang berlangsung kronik menginduksi gen UCP2 di selâ. Peningkatan UCP2 membantu untuk menghilangkan peningkatan membran potensial mitokondria secara aman dan mempromosikan detoksifikasi bahan bakar karena oksidasi bahan bakar ini menjadi semakin panas dibanding produksi ATP. Namun, hal ini terjadi dengan mengorbankan efisiensi sintesis ATP dan berdampak pada sekresi insulin Dengan kata lain, uncoupling fosforilasi oksidatif menyebabkan gangguan kemampuan sekresi insulin tetapi mengurangi produksi ROS, sebagai upaya sel-â mempertahankan kelangsungan hidupnya dalam keadaan jenuh bahan bakar. Sel-â mengkompensasi resistensi insulin dengan cara melakukan oksidasi glukosa tingkat tinggi atau mengalami defisiensi fungsi mitokondria yang beresiko terjadi kegagalan fungsional dan kerusakan oksidatif. (Lowell, 2005).

\section{Kerusakan Sel-â Pankreas pada Diabetes tipe- 2}

Kemampuan kompensasi sel â terbatas, jika reaksi kompensasi tidak mampu lagi dilakukan, maka selanjutnya terjadilah fase dekompensasi, yang ditandai salah satunya adalah penurunan massa selâ. Penurunan massa sel-â terjadi pada sebagian besar pasien diabetes. Pada DM tipe II terjadi penurunan massa sel-â sebesar $25-50 \%$ dan terjadi secara progresif. Penyebab penurunan massa sel-â pada DM tipe II belum dapat dipastikan, karena massa sel-â hanya dapat diukur post-mortem, tidak bisa ditentukan in vivo. Apakah pada DM tipe II memiliki massa sel-â lebih sedikit sejak awal kehidupan, ataukah terjadi kegagalan peningkatan massa sel-â saat menghadapi resistensi insulin ataukah juga terjadi kehilangan massa sel-â secara progresif. Kehilangan massa sel-â dapat disebabkan peningkatan apoptosis sel-â, reduksi pembentukan sel-â baru dari duktus eksokrin (neogenesis) / replikasi sel-â matur, atau keduanya (Rhodes, 2005).

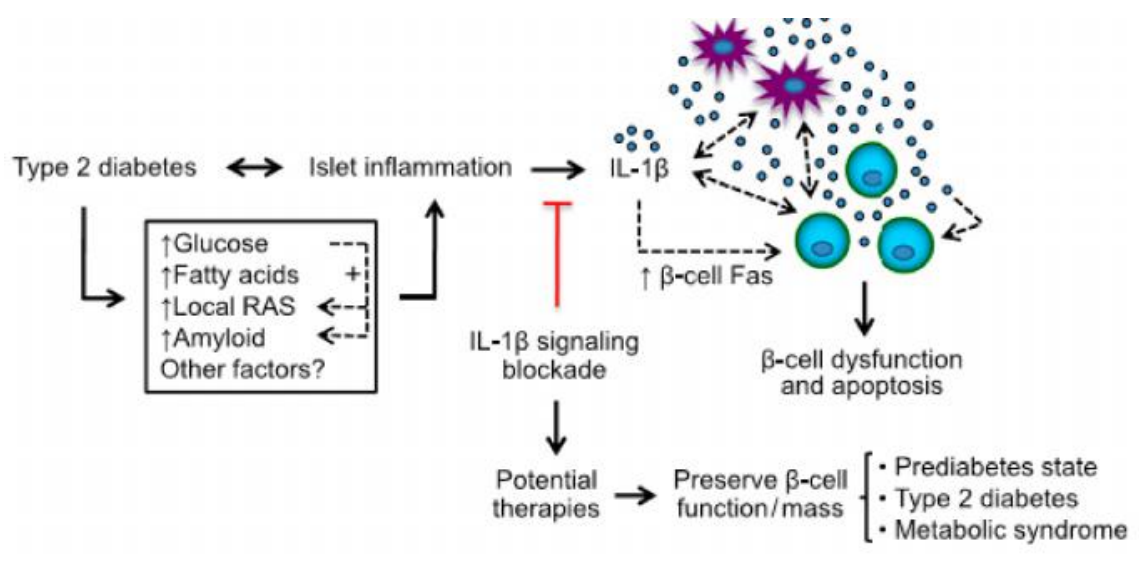

Islet resident

macrophages

Islet $\beta$-cells $\because \mathrm{IL}-1 \beta$

Gambar 2. Patofisiologi Kerusakan sel-â pada DM tipe II.(Marzban, 2015) 
Apoptosis merupakan mekanisme utama kematian sel-â pada DM tipe-II. Glukotoksisitas dan lipotoksisitas pada DM tipe II yang terus berlanjut menginduksi respon inflamasi pad sel islet dengan cara memproduksi sitokin dan kemokin serta mengaktivasi sistem immun innate. Pada awalnya respon inflamasi di islet memberikan efek protektif dan regeneratif dengan cara meningkatkan fungsi dan replikasi sel-â. Namun produksi sitokin dan kemokin yang terus menerus karena stres metabolik yang berkelanjutan, menyebabkan deregulasi jalur apoptosis dalam sel-â. Apoptosis pada DM tipe II tidak melalui jalur aktivasi NF-kB dan produksi NO. Peningkatan sitokin khususnya IL-1b dan IFNã menginduksi apoptosis melalui aktivasi jalur MAPK/JNK dan stimuli ekspresi reseptor FasL (Cnop, 2005).

Tingginya kebutuhan akan sintesa dan sekresi insulin dapat menyebabkan stres pada endoplasmik retikulum (ER), sebagai tempat assembly, pembentukan pro-insulin. Stres pada ER yang berat dan tidak diimbangi dengan UPR (unfolded protein response) yang adekuat akan menginisiasi terjadinya apoptosis (Kim, 2012). Peningkatan glukosa, FFA dan leptin yang berlangsung kronik menyebabkan inflamasi pulau Langerhans dan terjadilah peningkatan IL1â. IL1â menginduksi upregulasi Fas dan mengaktivasi jalur apoptosis (Marzban, 2015).
Mekanisme Regenerasi Pankreas secara

\section{Endogen}

Pankreas merupakan salah satu organ yang mempunyai kemampuan meregenerasi dirinya sendiri. Secara umum regenerasi dapat terjadi melalui tiga mekanisme, yang dilakukan oleh sel kompeten yang berbeda. Hiperplasia kompensasi adalah regenerasi dengan cara proliferasi yang dilakukan oleh sel yang telah terdiferensiasi (misalnya hepatosit). Regenerasi melalui dediferensiasi oleh sel matur membentuk sel progenitor yang mampu membelah. Regenerasi oleh cadangan sel punca / sel progenitor di jaringan yang mampu diaktivasi. Ketiga mekanisme tersebut mempunyai tujuan yang sama yaitu memperbaiki jaringan dan fungsinya setelah jaringan mengalami jejas (Stocum, 2002). Pankreas dapat meningkatkan massa sel-âa dengan cara meningkatkan replikasi sel-â matur dan meningkatkan proses maturasi sel punca menjadi sel-â. Sel punca merupakan sel lini pertama yang dapat berkembang menjadi sel dewasa / matur. Proses perkembangan tersebut meliputi neogenesis (dari sel progenitor yang ada di dalam pankreas), diferensiasi (dari sel punca embrional maupun dewasa), dan transdiferensiasi (dari sel punca di luar pankreas).

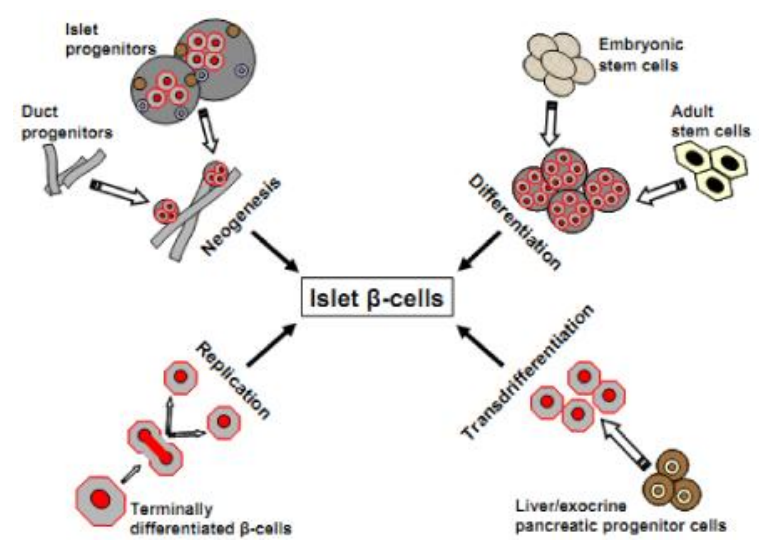

Gambar 3. Mekanisme pembentukan sel-â baru (Banerjee, 2005) 


\section{a. Regenerasi Pankreas Endogen oleh Sel-â matur}

Setiap sel dalam tubuh mempunyai potensi untuk replikasi (self-duplication) sekalipun sudah matur atau berada pada tahap akhir diferrensiasi. Kemampuan untuk bereplikasi ini bertujuan untuk menjamin kelangsungan hidup dan fungsi suatu jaringan atau organ. Namun kemampuan bereplikasi tersebut terbatas, demikian pula halnya dengan selâ pankreas. Dari keseluruhan populasi sel-â pankreas orang dewasa normal, jumlah sel-â pankreas yang secara aktual melakukan replikasi hanya 0,5-2\%. Pada kondisi normal dengan jumlah sel yang mengalami apoptosis (kematian sel secara alami) terbatas, tubuh masih mampu mempertahankan kondisi homeostasis bahkan jika komponen seluler dari salah satu jaringan tersebut memiliki tingkat replikasi tak terbatas (Banerjee, 2005).

Pada keadaan diabetes, kerusakan sel-â pankreas akibat inflamasi akan menstimuli tubuh untuk melakukan upaya perbaikan yang disebut sebagai regenerasi. Beberapa penelitian terakhir membuktikan bahwa sekalipun sel-â tidak memiliki potensi replikasi yang tinggi, tapi ia mampu meregenerasi massa selnya sendiri. Penelitian terdahulu membuktikan bahwa pankreas fetus tikus yang diinduksi STZ mampu melakukan regenerasi sel-â secara in vivo. Meningkatnya massa sel-â bukan karena hipertrofi tapi hiperplasia yang ditandai dengan meningkatnya densitas pulau Langerhans (Yamamoto, 2004 dalam Banerjee, 2005). Penelitian telah membuktikan bahwa diferensiasi dan maturasi (neogenesis) sel-â diregulasi antara lain oleh insulin (Guz, 2001 dalam Banerjee, 2005), dan gastrin/ EGF (Brand, 2002).

Pada tikus, faktor pertumbuhan seperti beta cellullin, kombinasi GLP-1/gastrin atau EGF/ gastrin potensial menstimuli replikasi sel-â pankreas (Suarez-Pinzon WL, 2008). Sampai saat ini belum diketahui dengan pasti bagaimana pankreas pada manusia dapat mempertahankan diri, melakukan regenerasi dan bagaimana peran faktor-faktor tersebut pada regenerasi pankreas. Namun pemberian agonis reseptor glukaogon-like peptide (GLP-1) / hormon incretin pada pasien DM tipe II terbukti dapat menstimuli sekresi insulin (Garber, 2011). GLP-1 meningkatkan proliferasi sel-â melalui beberapa jalur. Pertama, GLP-1 mengaktivasi IRS2 menyebabkan fosforilasi PKB dan inaktivasi forkhead$O$ transcription factor 1 (FOXO1) dan selanjutnya meningkatkan ekspresi gen pancreas-duodenum bomeobox1 (Pdx1) (Jetton, 2005). Kedua, GLP-1 mengaktivasi IRS2 dan protein kinase $\mathrm{B}$ (PKB) melalui $c A M P$ response element binding protein (CREB) juga menyebabkan transaktivasi epidermal growth factor receptor (EGFR). Aktivasi PKB juga memberikan efek protektif terhadap apoptosis melalui fosforilasi dan hambatan protein pro-apoptosis seperti BAD. Insulin dan IGF 1 dan 2 melalui IRS2 dan PKB juga meningkatkan ekspresi Pdx-1 (Prentki, 2006). Selain melalui GLP-1, FFA memberikan efek proliferasi melalui FFA receptor 1 (FFAR1 /GPR40) (Prentki, 2006).

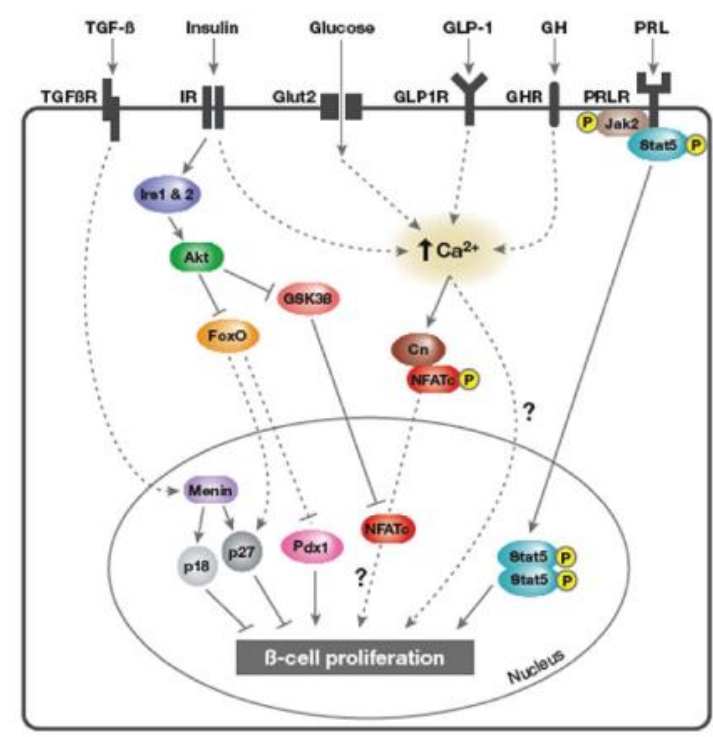

Gambar 4. Stimulator Proliferasi Sel-â (Suarez-Pinzon WL, 2008). 


\section{b. Regenerasi Pankreas Endogen oleh Adult Stem Cell/Progenitor Cell}

Pada regenerasi pankreas endogen in vivo, sel yang mensekresi insulin dapat berasal sel punca dewasa. Sumber sel punca dewasa antara lain dari pankreas (sel eksokrin, sel duktus, sel islet) atau direkrut dari organ lain seperti sumsum tulang, hepar, intestin, dan sirkulasi (Gambar 5). Sel punca dari sumsum tulang melalui sirkulasi menuju ke jaringan lain, usus, hepar, pankreas dan darah. Di pankreas sel punca tersebut akan berdiferensiasi menjadi sel-â. Sel punca dari organ lain akan berdiferensiasi atau transdiferensiasi menjadi sel-âa .

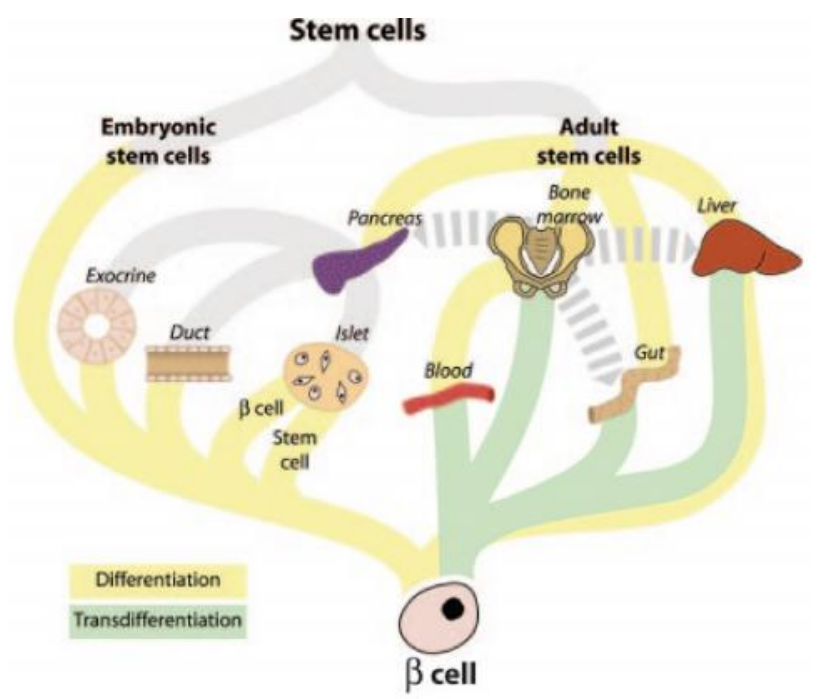

Gambar 5. Sumber Sel Punca Pankreatikus (Soria, 2005)

Pada keadaan tertentu misalnya hiperglikemia, kemampuan regenerasi tersebut menurun dan secara progresif dapat tejadi kerusakan sel-â pankreas sehingga terjadi diabetes mellitus. Beberapa faktor yang diduga memberikan regulasi negatif pada proses diferensiasi dan ekspansi sel punca dewasa antara lain diet yang tidak seimbang, malnutrisi, supernutrisi, dan stres oksidatif. Pada DM tipe II terjadi perubahan niche sel punca yang mensupresi kemampuan regenerasi jaringan. Ekspresi VEGF dan Wnt3a endogen menurun pada mencit diabetik. VEGF merupakan faktor proangiogenik yang mendukung penyembuhan luka dan regenerasi jaringan melalui neovaskularisasi dan proliferasi MSC. Wnt3a merupakan suatu sinyal autokrin yang dilepaskan MSC dan berperan sebagai faktor proliferasi, mendukung proses proliferasi, diferensiasi, migrasi dan invasi MSC ke area injuri (Shin, 2012)

Pada DM tipe II terjadi perubahan niche sel punca yang mensupresi kemampuan regenerasi jaringan. Ekspresi VEGF dan Wnt3a endogen menurun pada mencit diabetik. VEGF merupakan faktor proangiogenik yang mendukung penyembuhan luka dan regenerasi jaringan melalui neovaskularisasi dan proliferasi sel punca mesenkimal (MSC). Wnt3a merupakan suatu sinyal autokrin yang dilepaskan MSC dan berperan sebagai faktor proliferasi, mendukung proses proliferasi, diferensiasi, migrasi dan invasi MSC ke area injuri (Shin, 2012)

\section{Jintan Hitam}

Jintan hitam (Nigella sativa) adalah tanaman yang dikenal dengan berbagai nama, antara lain black seed, black caraway, natura seed, black cumin, nigella sativa, kaluduru, Al Habba Al Sauda atau Al Habba Al Barokah dalam bahasa Arab. Tanaman jintan hitam merupakan jenis tanaman rempah yang tergolong dalam famili Ranunculaceae. Tanaman ini tumbuh di berbagai daerah di dunia khususnya di negara timur tengah dan banyak digunakan sebagai bumbu penyedap makanan maupun sebagai obat tradisional (Paarakh, 2010). Jintan hitam digunakan 
sebagai herbal pengobatan sejak 2000-3000 tahun sebelum Masehi dan tercatat dalam banyak literatur kuno oleh peneliti seperti Ibnu Sina (980 - 1037 M), dan Al-Biruni (973-1048 M). Abu Hurairah pernah mendengar Rasulullah Muhammad SAW bersabda: "Pada Habbatussauda ada obat bagi segala jenis penyakit kecuali Al-Sam, yaitu maut" .

Kedudukan tanaman jintan hitam dalam sistematik tumbuhan (taksonomi) sebagai berikut

$$
\begin{array}{ll}
\text { Kingdom } & \text { Plantae } \\
\text { Divisi } & \text { : Magnoliophyta } \\
\text { Kelas } & \text { : Magnoliopsida } \\
\text { Ordo } & \text { Ranunculales } \\
\text { Famili } & \text { : Ranunculaceae } \\
\text { Genus } & \text { : Nigella } \\
\text { Spesies } & \text { : Nigella sativa }(\mathrm{Yu}, 2015)
\end{array}
$$

Tanaman jintan hitam merupakan tanaman semak dengan ketinggian lebih kurang $30 \mathrm{~cm}$. Ekologi dan penyebaran tanaman ini tumbuh mulai dari daerah Levant di Mediterania Timur Samudra Indonesia sebagai gulma semusim dengan keanekaragaman yang kecil. Budi daya perbanyakan tanaman dilakukan dengan biji (Botnick, 2012)

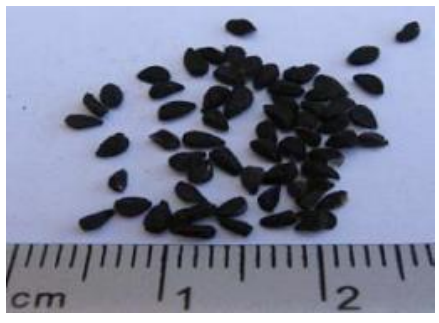

Gambar 6. Biji Jintan Hitam (N. Sativa) (Mathur, 2011)
Jintan hitam memiliki kelopak bunga kecil, berjumlah lima, berbentuk bulat telur., ujungnya agak meruncing sampai agak tumpul.. Buah jintan hitam seperti polong, bulat panjang, dan coklat kehitaman. Di dalam buah tersebut terdapat biji. Bijinya kecil, bulat, hitam, jorong bersusut tiga tidak beraturan dan sedikit berbentuk kerucut, panjang $3 \mathrm{~mm}$, serta berkelenjar (Mathur, 2011).

\section{Kandungan dan Efek Antidiabetik Biji Jintan Hitam}

Biji jintan hitam (Nigella sativa L.) mengandung 35-41\% fixed oil dan $0,5-1,6 \%$ volatil oil (Botnick, 2012). Terdapat 8 asam lemak dan 32 senyawa $(86,7 \%)$ telah diidentifikasi dari fixed oil. Beberapa kandungan asam lemak utama dalam biji jintan hitam yaitu asam linoleic (55,6\%), asam oleic $(23,4 \%)$ dan asam palmatic (12,5\%) (Nickavar,2003). Fraksi utama volatile oil dari biji jintan hitam matur adalah monoterpene dan sisanya sesquiterpene. Monoterpene biji jintan hitam berupa $27,8-57 \%$ thymoquinone dan sisanya monoterpen yang lain seperti p-cymene $(7,1-$ 15,5\%), ä-terpinene, á-pinene, â-pinene, á-thujene, dan carvacrol (5,8-11,6\%). Thymoquinone merupakan bioaktif utama biji jintan hitam. Sesquiterpene berupa longifolene. Indazole alkaloid, seperti nigellicine dan nigellidine, dan saponin juga dapat diisolasi dari biji jintan hitam (Botnick, 2012; Barnosa, 2015).

Tabel.1 Komponen Utama Biji Jintan Hitam dan Asam lemak utama (dikutip dari Barnosa, 2015)

\begin{tabular}{|l|c|l|c|}
\hline \multicolumn{2}{|c|}{ Komponen utama dalam biji } & \multicolumn{2}{c|}{ Asam lemak utama } \\
\hline Kamponen & $\begin{array}{c}\text { Persentase } \\
(\mathrm{w} / \mathrm{w})\end{array}$ & Asam lemak & $\begin{array}{c}\text { Persentase dari } \\
\text { total asam lemak }\end{array}$ \\
\hline Lemak & $30-378$ & Linoleat & $50-87$ \\
\hline Protein & 30 & Palmitat & $6-12,5$ \\
\hline Serat & 20 & Oleat & $19,9-23,4$ \\
\hline Uap & $6-10$ & Margarik & 10,3 \\
\hline Ash & $2,5-6$ & & \\
\hline
\end{tabular}

Biji jintan hitam juga mengandung oxy-coumarin, 6-methoxycoumarin, dan 7-hydroxy-coumarin, saponin alpha-hedrin, steryl-glucoside, flavonoids, tannins, asam amino esensial, asam askorbat, besi dan kalsium (Randhawa 2008). Selain itu, biji jintan hitam juga mengandung senyawa fenchone (1,1\%), terpinen-4-ol $(0,7 \%)$, carvacrol (3\%), dan citronellol (Paarakh, 2010). 
Tabel.2 Mineral dan Vitamin utama dalam biji jintan hitam (dikutip dari Barnosa, 2015)

\begin{tabular}{|c|c|l|c|}
\hline \multicolumn{2}{|c|}{ Mineral } & \multicolumn{2}{c|}{ Vitamin } \\
\hline mineral & $\mathrm{mg} / 100 \mathrm{~g}$ & \multicolumn{1}{c|}{ vitamin } & $\mu / 100 \mathrm{~g}$ \\
\hline $\mathrm{K}$ & $823-1180$ & $\mathrm{~B} 1$ (thiamin) & $831-1540$ \\
\hline $\mathrm{Mg}$ & 80 & $\mathrm{~B} 2$ (riboflavin) & 63 \\
\hline $\mathrm{Ca}$ & $160-188$ & $\mathrm{~B} 6$ (pyridoxin) & 789 \\
\hline $\mathrm{Zn}$ & 2,5 & PP (niacin) & $5700-6311$ \\
\hline $\mathrm{Mn}$ & 1,5 & Asam folat & 42 \\
\hline $\mathrm{Cu}$ & $0,9-1,8$ & & \\
\hline $\mathrm{Fe}$ & $10,5-65$ & & \\
\hline
\end{tabular}

Secara umum biji jintan hitam terdiri dari dua bagian yaitu kulit biji (seed coat) dan bagian dalam biji (endosperm dan embrio). Volatile oil termasuk tymoquinone terakumulasi pada lapisan dalam kulit biji, sehingga untuk ekstraksi tidak dapat langsung dari biji utuh jintan hitam namun perlu dilakukan perusakan kulit terlebih dahulu. Alkaloid nigellidine dan nigellicine terakumulasi hampir seluruhnya di kulit biji dan sedikit di bagian dalam, sedangkan saponin á-bederin terdistribusi rata di kulit maupun bagian dalam biji jintan hitam (Botnick, 2012)

Efek antidiabetik biji jintan hitam telah banyak dibuktikan melalui penelitian eksperimental. Efek antidiabetik biji jintan hitam antara lain melalui efek protektif sel beta terhadap stres oksidatif (Kanter, 2004), induksi proliferasi sel-â (Kanter, 2003), menurunkan kadar MDA di jaringan pankreas (Kanter, 2004), penurunan kadar plasma hormon leptin, meningkatkan ekspresi Glut-4 dan penurunan glukoneogenesis di hati (Ali, 2011).

Penelitian klinik juga telah membuktikan efek anti diabetik biji jintan hitam. Pemberian minyak jintan hitam 2,5 mL dua kali sehari selama 6 minggu pada pasien sindrome metabolik terbukti secara signifikan dapat menurunkan GDP dan LDL serta menurunkan LDL (Najmi, 2009). Penurunan signifikan pada GDP dan peningkatan insulin telah diobservasi pada 41 orang penderita DM tipe II yang menggunakan terapi minyak jintan hitam selama 40 hari. Tidak terjadi perubahan kadar ureum, SGPT, lekosit total dan platelet (Bilal, 2009). Pemberian adjuvan biji jintan hitam (1, 2, 3 g/hari) selama 3 bulan pada 94 pasien DM tipe II yang juga mendapat terapi metformin terbukti secara signifikan menurunkan GDP, GD2jPP dan HbA1C (Barnosa, 2010). Pengaruh biji jintan hitam pada gula darah, serum lipid dan tekanan darah juga pernah dilaporkan oleh Qidwai, 2009. Pemberian suplemen biji jintan hitam bersama OAD pada penderita DM tipe II terbukti dapat menurunkan status redoks pasien (Kaatabi, 2015)

\section{Potensi Biji Jintan Hitam dalam Regenerasi Pankreas secara Endogen}

Beberapa penelitian terdahulu telah membuktikan potensi biji jintan hitam dalam regenerasi pankreas. Pemberian injeksi minyak jintan hitam 0,20mL/kg / hari secara i.p selama 30 hari pada tikus yang telah diinduksi streptozotocin (STZ) terbukti secara histologis terjadi parsial regenerasi / proliferasi sel-â pankreas, yang ditandai dengan ukuran pulau Langerhans meningkat, immunoreaktifitas terhadap insulin terekspresi positif kuat pada pulau Langerhans tersebut (Kanter et al, 2003) dan terjadi peningkatan kada insulin serum (Kanter et al, 2004). Penelitian Bilal, 2009 membuktikan bahwa terjadi peningkatan kadar insulin dan penurunan gula darah puasa (GDP) signifikan pada 41 orang pasien DM tipe II setelah pemberian terapi minyak biji jintan hitam selama 40 hari. Terjadi peningkatan kadar insulin menunjukkan perbaikan fungsi pankreas. Pemberian Hal tersebut memunculkan dugaan bahwa biji jintan hitam berpotensi membantu regenerasi pankreas secara endogen. Biji jintan hitam merupakan nutriceutical yang mengandung beberapa bioaktif (multicompound) antara lain thymoquinone, saponin a-hederin asam linoleat, asam oleat, dan suatu alkealoid nigellone (Rooney, 2005; Paarakh, 2010). Kelima bioaktif tersebut dapat memberikan efek anti diabetik diduga melalui efek regenerasi sel beta pankreas. Regenerasi sel-â secara endogen bisa terjadi melalui induksi proliferasi sel-â matur, diferensiasi / transdiferensasi dari sel punca / sel progenitornya, atau dengan cara mempengaruhi beberapa komponen di dalam niche sel punca, sehingga mampu mengaktivasi sel punca yang sedang dalam keadaan tidak aktif (quiscent). 
Thymoquinone (TQ) sebagai bioaktif utama biji jintan hitam telah dibuktikan selain memberikan efek antiinflamasi juga efek pro inflamasi Penelitian terdahulu telah membuktikan TQ bekerja sebagai agonis speseifik G-protein coupled receptor (GPCR) sel makrofag. Aktivasi GPCR selanjutnya akan mengaktivasi protein sub unit Gái dan matriks metaloproteinase-9 (MMP-9). MMP-9 akan mengaktivasi neuraminidase-4 (Neu4) sialidase pada membran sel. Aktivasi Neu4 akan menginduksi pembentukan kompleks MyD88/ TLR4 dan selanjutnya akan mengaktivasi NF-B (Abdulkhalek, 2013). Aktivasi NF-kB melalui jalur non-canonical yaitu ynag melibatkan cRel, diduga dapat memberikan efek proliferasi sel-â dengan menginduksi cMyc yang ada di dalam niche sel punca pankreas.Efek proliferatif NS / thymoquinone juga pernah dibuktikan pada saraf (Kanter, 2008; Kaleem, 2006, Bai, 2013). TQ juga bekerja melalui TLR4, aktivasi GPCR maupun TLR4 dapat menyebabkan transaktivasi reseptor EGF (EGFR) tanpa adanya ligan EGF (Evaul, 2008). Aktivasi EGFR di pankreas menyebabkan proliferasi sel-â. Di lain pihak, TQ sebagai agonis GPCR di makrofag selanjutnya akan mengaktivasi jalur p38-mitogen-protein kinase (p38/MAPK) (Finlay, 2010; Yu, 2015). Aktivasi jalur MAPK akan menyebabkan aktivasi jalur Wnt/â-catenin. Aktivasi jalur Wnt/catenin mengaktifkan cyclin D2 yang bertanggung jawab pada self renewal sel punca mesenkimal (MSC) (Stewart,2015). Sel punca MSC yang sudah teraktivasi akan mengeluarkan faktor pertumbuhan HGF. Aktivasi MAPK juga akan mengaktivasi protein regulator transkripsi c-myc. HGF , c-myc dan cyclin D2 merupakan bagian dari niche cell yang berperan penting dalam induksi quiescent endogenous mesencymal stem cell untuk regenerasi sel-â pankreas. Terjadinya differensiasi dan regenerasi sel-â pankreas akan ditandai dengan meningkatnya ekspresi faktor transkripsi pankreas, Pdx-1 dan Nkx6.1(Roux, 2004).

Saponin menstimuli pelepasan GLP-1(Liu, 2013). Aktivasi reseptor GLP-1 memberikan efek proliferasi sel-â (Campbell, 2013). Saponin a-bederin dan nigellone merupakan agonis peroxisome proliferator-activated receptor (PPARã). Aktivasi jalur PPARã berperan dalam diferensiasi / maturasi sel-â (Moibi, 2010). Dengan aktivasi sel punca endogen dan proliferasi - diferensisasi sel-â matur akan terjadi regenerasi sel-â pankreas, sehingga menambah jumlah sel-â dan selanjutnya dapat menghasilkan insulin secara adekuat dan gula darah akan terkontrol. Peningkatan sintesa dan sekresi insulin ditandai dengan peningkatan kadar c-peptide sebagai precursor insulin (Banerjee, 2005).

Peran asam lemak bebas tak jenuh terhadap proliferasi sel-â pankreas masih kontroversi. Massa sel-â tergantung pada keseimbangan antara proliferasi( dari replikasi sel-â yang ada dan dari pembentukan sel-â baru) dan kematian sel-â (apoptosis). Pada mencit dibuktikan bahwa mekanisme adaptif paling dominan pankreas dalam menghadapi keadaan hiperglikemi adalah proliferasi sel-â karena glukosa merupakan stimulator proliferasi sel beta. Penelitian oleh Pascoe membuktikan bahwa asam lemak bebas menghambat glukosa menginduksi proliferasi sel beta pada mencit melalui hambahatan siklus sel p16 dan p18 (Pascoe, 2012). Namun hasil tersebut tidak tepat untuk manusia. Studi dari hasil otopsi menunjukkan bahwa massa sel-â pankreas pada pasien obese diabetik berkurang $50-60 \%$ dibanding pasien obese non-diabetik (Klöppel G, 1985). Kehilangan massa sel-â pada pasien DM tipe II terutama disebabkan oleh meningkatnya apoptosis (Butler et al, 2003). Penelitian lain membuktikan peran asam lemak bebas pada proliferasi sel dari sisi yang berbeda. Asam linoleat dan asam oleat mempengaruhi proliferasi sel punca, ekspresi gen, sekresi protein, dan migrasi sel punca mesenkimal (MSC). Asam linoleat menginduksi proliferasi sel punca embrional mencit ( Kim et al, 2009). Penelitian invitro membuktikan asam linoleat juga mempengaruhi engrafment MSC menuju area jejas. Diketahui bahwa sel punca mesenkimal untuk regenerasi sel-â pankreas dapat berasal dari antara lain dari pankreas (sel eksokrin, sel duktus, sel islet ) atau direkrut dari organ lain seperti sumsum tulang, hepar, intestin, dan sirkulasi (Gambar 5). Di pankreas, sel punca mesenkimal yang bermigrasi dari organ-organ tersebut akan berdiferensiasi menjadi sel-â. Peningkatan kemampuan migrasi MSC setelah pemberian asam linoleat, tidak melalui jalur NF-kB, PPAR-ã ataupun HIF-1á, namun melalui peningkatan sekresi sitokin IL-6, IL-8 dan faktor pertumbuhan VEGF yang meregulasi respon selular lokal daerah jejas (Smith et al, 2012). 


\section{KESIMPULAN}

Biji jintan hitam (Nigella sativa) berpotensi sebagai terapi tambahan pada pasien diabetes mellitus. Mekanisme penting dari biji jintan hitam adalah kemampuannya dalam membantu regenerasi sel-â pankreas secara endogen, sehingga dapat mempertahankan / meningkatkan massa sel-â. Beberapa bioaktif dari biji jintan hitam yang berperan dalam regenerasi sel-â pankreas adalah thymoquinone, asam lemak tak jenuh (asam linoleat dan asam oleat), saponin a-hederin dan nigellone.

\section{DAFTAR PUSTAKA}

Abdulkhalek S, Hrynyk M, Szewczuk MR, 2013, A novel G-protein-coupled receptor-signaling platform and its targeted trajintan hitamlation in human disease, Research and Reports in Biochemistry 3 ; 17-30

American Diabetes Association (ADA), 2004, Global Prevalence of Diabetes; Estimates for the year 2000 and projectiojintan hitam for 2030

Bai T, Lian L, Wu Y, Wan Y, Nan J, 2013, Thymoquinone attenuates liver fibrosis via PI3K and TLR4 signaling pathways in activated hepatic stellate cells, International Immunopharmacology Volume 15, Issue 2, Pages 275-281

Banerjee M, Kanitkar M, Bhonde RR, 2005, Endogenous Pancreatic Regeneration, Review of Diabetic Studies Vol. 2 A" No. 3 A"p 165-176

Bamosa AO, 2015, A Review on the Hypoglycemic Effect of Nigella Sativa and Thymoquinone, Saudi Journal of Medicine \& Medical Sciences Volume. 3 , Issue 1, 2-7

Bilal A, Masud T, Uppal AM, Naveed AK, 2009, Effects of Nigella sativa oil on some blood parameters in type 2 diabetes mellitus patients. Asian J. Chem., v.21, p.5373-5381.

Botnick I, Xue W, Bar E, Ibdah M, Schwartz A, Joel DM, Lev E, Fait A and Lewijintan hitamohn E, 2012, Distribution of Primary and Specialized Metabolites in Nigella sativa Seeds, a Spice with Vast Traditional and Historical Uses, Molecules, 17, 10159-10177;
Brand SJ, Tagerud S, Lambert P, Magil SG, Tatarkiewicz K, Doiron K, Yan Y, 2002 Pharmacological treatment of chronic diabetes by stimulating pancreatic â-cell regeneration with systemic co-administration of EGF and gastrin. Pharmacol Toxicol 91:414-420

Butler AE, Janson J, Bonner-Weir S, Ritzel R, Rizza RA, Butler PC, 2003, â-cell deûcit and increased b-cell apoptosis in humans with type 2 diabetes, Diabetes 52:102-110

Campbell JE, Drucker DJ, 2013, Pharmacology, physiology, and mechanisms of incretin hormone action. Cell Metab 2013;17:819837

Cnop M, Welsh N, Jonas J, Jo“ rjintan hitam A, Lenzen S, Eizirik DL, 2005, Mechanisms of Pancreatic â-Cell Death in Type 1 and Type 2 Diabetes : Many Differences, Few Similarities, Diabetes 54 (Suppl. 2) S97-S107

Evaul, K. and S.R. Hammes, 2008, Cross-talk between G Protein-coupled and Epidermal Growth Factor Receptors Regulates Gonadotropin-mediated Steroidogenesis in Leydig Cells. J. Biol. Chem.,283(41): 2752527533

Finlay TM, Abdulkhalek S, Gilmour A, 2010. Thymoquinone-induced Neu4 sialidase activates NFkappaB in macrophage cells and proinflammatory cytokines in vivo. Glycoconj J. 2010;27(6):583-600.

Garber AJ, 2011, Long-acting glucagon-like peptide 1 receptor agonists: A review of their efficacy and tolerability. Diabetes Care 34 Suppl 2:S279-S284.

Guz Y, Nasir I, Teitelman G, 2001 Regeneration of pancreatic beta-cells from intra-islet precursor cells in an experimental model of diabetes. Endocrinology. 142:4956-4968.IDF (International Diabetes Federation tahun 2012

Jetton, T.L., et al. 2005. Mechanisms of compejintan hitamatory beta-cell growth in ijintan hitamulin-resistant rats: roles of Akt kinase. Diabetes. 54:2294-2304

Kaatabi H, Bamosa AO, Badar A, Al-Elq A, Abou-Hozaifa B, Lebda F, 2015, Nigella sativa Improves Glycemic Control and Ameliorates Oxidative Stress in Patients with Type 2 Diabetes Mellitus: Placebo Controlled 
Participant Blinded Clinical Trial, PLOS ONE | DOI:10.1371/journal.pone.0113486

Kaleem M, Kirmani D, Asif M., Ahmed Q, Bano B, 2006, Biochemical Effects of Nigella sativa L seed in Diabetic Rats, Indian Journal of Experimental Biology vol 44 pp 745748

Kanter M, Meral I, Yener Z, Ozbek H, Demir H, 2003 Partial regeneration/proliferation of the beta-cells in the islets Of Langerhajintan hitam by Nigella sativa L. in streptozotocininduced diabetic rats. Tohoku J Exp Med 201(4):213-219.

Kanter M, 2008, Effects of Nigella sativa and its major cojintan hitamtituent, thymoquinone on sciatic nerves in experimental diabetic neuropathy. Neurochem Res 33(1):87-96.

Kim MH, Kim MO, Kim YH, Kim JS, Han HJ, 2009,. Linoleic acid induces mouse embryonic stem cell proliferation via $\mathrm{Ca} 2+/ \mathrm{PKC}$, PI3K/Akt, and MAPKs, Cell Physiology Biochemitry 23:53-64.

Kim MK, Kim HS, 2012, Endoplasmic Reticulum Stress and Ijintan hitamulin Biosynthesis: A Review/ Hindawi Publishing Corporation Experimental Diabetes Research Volume 2012, Article ID 509437, 7 pages

Klöppel G, Löhr M, Habich K, Oberholzer M, Heitz PU, 1985,. Islet pathology and the pathogenesis of type 1 and type 2 diabetes mellitus revisited. Surv Synth Pathol Res 4:110-125

Li L, Seno M, Yamada H, Kojima I. Betacellulin improves glucose metabolism by promoting conversion of intra-islet pre-cursor cells to â-cells in streptozotocin-treated mice. American Journal of Physiology Endocrinology and Metabolism 2003. 285:577-583

Li Y, Cao X, Li LX, Brubaker PL Edlund H, Drucker DJ, 2005, â-Cell Pdx1 Expression Is Essential for the Glucoregulatory, Proliferative, and Cytoprotective Actiojintan hitam of Glucagon-Like Peptide-1, Diabetes 54:482-491

Liu C, Zhang M, Hu M, Guo H, Li J, Yu Y, Jin S, Wang X, Liu L, Liu X, 2013, Increased glucagon-like peptide-1 secretion may be involved in antidiabetic effects of gijintan hitamenosides, Journal of Endocrinology 217, 185-196

Lowell, B.B., and Shulman, G.I. 2005. Mitochondrial dysfunction and type 2 diabetes. Science. 307:384-387

Marzban L, 2015, New Ijintan hitamights Into the Mechanisms of Islet Inûammation in Type 2 Diabetes, Diabetes 2015;64:1094-1096

Mathur ML, Gaur J, Sharma R, Haldiya KR, 2011, Antidiabetic Properties of a Spice Plant Nigella sativa, J Endocrinol Metab 2011;1(1):1-8

Moibi JA, Gupta D, Jetton TL, Peshavaria M, Desai R, Leahy JL, 2010, Peroxisome Proliferator-Activated Receptor-ã Regulates Expression of PDX-1 and NKX6.1 in IJINTAN HITAM-1 Cells

Najmi A, Haque S.F, Khan RA, Nasiruddin, M, 2009.Therapeutic Effect of Nigella Sativa oil on different clinical and biochemical parameters in metabolic syndrome. Int. J. Diabetes Metabol., v.16, p.85-87.

Nickavar B, Mojaba F, Javidniab K, and Amoli MAR, 2003, Chemical Composition of the Fixed and Volatile Oils of Nigella sativa L.from Iran, Naturforsch. 58c, 629-631

Paarakh PM, 2010, Nigella sativa Linn-A comprehejintan hitamive review, Indian Journal of Natural Product and Resources, vol1 (4), pp 409-429

Pascoe J, Hollern D, Stamateris R, et al., 2012, Free fatty acids block glucose-induced b-cell proliferation in mice by inducing cell cycle inhibitors p16and p18. Diabetes 61:632-641

Prentki M, Nolan CJ, 2006, Islet b cell failure in type 2 diabetes, J. Clin. Invest. 116:18021812

Qidwai W, Hamza HB, Qureshi, R, Gilani A, , 2009, Effectiveness, safety, and tolerability of powdered Nigella sativa (Kalonji) seed in capsules on serum lipid levels, blood sugar, blood pressure, and body weight in adults: results of a randomized, double-blind controlled trial. J. Alt. Compl. Med. v.15, p.639-644. 
Rhodes CJ, 2005 Type 2 diabetes: a matter of $\hat{a}^{-}$ cell life and death? Science 307:380-384

Roduit, R., et al. 2004. A role for the malonyl$\mathrm{CoA} /$ long-chain acyl-CoA pathway of lipid signaling in the regulation of ijintan hitamulin secretion in respojintan hitame to both fuel and nonfuel stimuli. Diabetes. 53:1007-1019.

Rooney S and Ryan MF, 2005, Effects of Alphahederin and Thymoquinone, cojintan hitamtituents of Nigella sativa, on Human Cancer Cell Lines, Anticancer Research 25: 2199-2204

Roux PP and Blenis J, 2004, ERK and p38 MAPKActivated Protein Kinases: a Family of Protein Kinases with Diverse Biological Functiojintan hitam, Microbiology And Molecular Biology Reviews, Vol. 68, No. 2, p. 320-344

Saini V, 2010, Molecular mechanisms of ijintan hitamulin resistance in type 2 diabetes mellitus. World Journals Diabetes 1(3): 68-75

Shin L, Peterson DA, 2012, Impaired Therapeutic Capacity of Autologous Stem Cells in a Model of Type 2 Diabetes, Stem Cells Translational Medicine 1:125-135

Smith AN, Muffley LA, Bell AN, Numhom S, dan Hocking AM, 2012, Unsaturated fatty acids induce mesenchymal stem cells to increase secretion of angiogenic mediators, Journal Cell Physiology. ; $227(9)$ : 3225-3233

Stewart AF, Hussain MA, Ocana AG, Vasavada RC, Bhusnan A, Bernal-Mizrachi E Kulkarni RN, Mizrachi EB, 2015, Human â-cell proliferation and intracellular signaling: Part 3, Diabetes 64:1872-1885

Stocum DL, 2002, Regenerative biology and medicine, Journal of Musculoskeletal Neuron Interaction 2(3):270-273

Suarez-PinzonWL, Power RF, Yan Y, 2008,Combination therapy with glucagonlike peptide-1 and gastrin restores normoglycemia in diabetic NOD mice. Diabetes 57:3281-3288

WHO., 2016. WHO methods and data sources for country-level causes of death 2000-2015. http://www.who.int

Yamamoto M, Yasuda M, Hori A, Arishima K, Eguchi Y, 2004, Recovery in the fetal pancreatic islet following fetal administration of streptozotocin in the rat in vivo and in vitro. Anat Rec A Discov Mol Cell Evol Biol ; 281:1319-1325.

Yu S, Kim, S, 2015, The thymoquinone-induced production of reactive oxygen species promotes dedifferentiation through the ERK pathway and inflammation through the p38 and PI3K pathways in rabbit articular chondrocytes, International Journal Of Molecular Medicine 35: 325-332 